\title{
АНАЛІЗ МІЖНАРОДНИХ ПРАВОВИХ СТАНДАРТІВ \\ ТА НАЦІОНАЛЬНОГО ЗАКОНОДАВСТВА У СФЕРІ ЗАБЕЗПЕЧЕННЯ КОНСТИТУЦІЙНОГО СТАТУСУ ПЕРЕМІЩЕНИХ ОСІБ
}

Постановка проблеми у загальному вигляді та ії зв'язок із важливими науковими чи практичними завданнями. Сучасне вимушене переміщення осіб у світі загалом та Україні зокрема, спричинене цілою низкою різноманітних факторів, $\mathrm{e}$ одним з найбільших викликів, що постали перед світовою спільнотою. За даними Агентства ООН по справах біженців (УВКБ ООН), глобальне переміщення населення досягло нового рівня у 68,5 мільйона осіб (що на 2,9 мільйона більше, ніж у 2016 році), серед яких рекордні 40 мільйонів були переміщені в межах власних країн.

Аналіз останніх досліджень і публікацій, в яких започатковано розв'язання цієї проблеми, виділення не вирішених раніше частин загальної проблеми. Над проблемами правового регулювання вимушених переселенців працювали М.П. Кобець, К.О. Крахмальова, О.А. Фесенко, В.І. Михайловський та інші. Разом із тим актуальність та важливість досліджуваних питань наразі не втрачає свого теоретичного та практичного значення.

Формулювання мети та завдань дослідження. Мета статті - аналіз міжнародної та національної нормативно-правової бази у сфері вимушеного переміщення.

Виклад основного матеріалу. За останні півстоліття концепція державного регулювання інституту переміщених осіб у світі суттєво змінилася. Так само і Україна, перебуваючи в умовах масштабної правової реформи, починаючи з моменту проголошення іï демократичною, соціальною і правовою державою, йде шляхом правонаступності кращого світового досвіду в сфері забезпечення прав різних категорій переміщених осіб. Процеси соціальної адаптації переміщених осіб, гарантії захисту їхніх прав, гарантованих Конституцією України, в тому числі виборчих, трудових та соціальних прав, захисту права власності, відновлення втрачених ідентифікуючих документів, прав у сфері доступу до інформації і державних послуг, надання високоякісних послуг з економією часу та зусиль вказаної категорії громадян, відновлення віри в уряд, якість державної підтримки зумовлюють необхідність формування нових наукових підходів до осмислення конституційно-правового статусу переміщених осіб в Україні.

Тривалий час у міжнародному праві питанню правового регулювання внутрішнього переміщення населення не приділялось належної уваги, а також визначалась його виключна приналежність до внутрішньої компетенції кожної окремої держави. Чинні тоді норми щодо осіб, що вибули за межі своєї держави і шукають міжнародного захисту, певним чином стосувалися і внутрішнього переміщення, однак комплексно питання правового статусу вимушених переселенців на міжнародно-правовому рівні регламентовано не було. 3 метою конкретизації та створення грунтовної нормативно-правової бази Економічна та Соціальна Рада $\mathrm{OOH}$ 
схвалила Керівні принципи з питання переміщених осіб усередині країни (Guiding Principles on Internal Displacement, 1998).

Доцільно зазначити, що фундаментом правової бази вказаного нормативно-правового акта є Загальна декларація прав людини (Universal Declaration of Human Rights (UDHR, 1948 р.), Міжнародний пакт про громадянські та політичні права (International Covenant on Civil and Political Rights (ICCPR, 1976 р.), Конвенція про права дитини (Convention on the Rights of the Child, 1989 р.), Конвенція проти катувань та інших жорстоких, нелюдських або принижуючих гідність видів поводження та покарання (Convention against Torture and Other Cruel, Inhuman or Degrading Treatment or Punishment, 1987 р.), Конвенція про статус біженців (Convention Relating to the Status of Refugees, 1948 р.), Женевські конвенції про захист жертв війни (Geneva Convention relative to the Protection of Civilian Persons in Time of War, 1949 р.), Конвенція про запобігання злочину геноциду та покарання за нього (Convention on the Prevention and Punishment of the Crime of Genocide, 1948 р.) та інші.

Керівні принципи ООН з питання переміщених осіб усередині країни слід розглядати як уніфікований документ, що містить 30 стандартів та узагальнює наявні в міжнародному праві засади та керівні принципи у сфері захисту прав переміщених осіб, деталізує права, гарантії захисту та допомоги під час переміщення. Не зважаючи на те, що Керівні принципи не є обов'язковим юридичним документом, він набув значного авторитету з моменту прийняття та рекомендований Радою Свропи своїм членам керуватися вказаним актом під час розроблення національного законодавства та в правозастосовній практиці у цій сфері.

Структурно Керівні принципи побудовані навколо фаз переміщення та стосуються захисту від вимушеного переміщення (п. 5-9), захисту під час переміщення (п. 10-23), системи гуманітарної допомоги (п. 24-27) і захисту під час повернення, місцевої інтеграції як у регіони, звідки були переміщені особи, так і переселення в інші частини країни (п. 28-30) [3].

Керівні принципи ООН з питань внутрішнього переміщення визначають «внутрішньо переміщеними особами осіб або групи осіб, які були змушені покинути свої будинки або місця постійного проживання, зокрема в результаті або з метою уникнення наслідків збройного конфлікту, ситуації загального насильства, порушень прав людини, стихійних або антропогенних лих і які не перетнули міжнародно визнаний державний кордон» [1].

Варто звернути увагу, що у визначенні поняття «внутрішньо переміщена особа» зроблено акцент на двох фундаментальних елементах: по-перше, примусовий або будь-яким іншим чином недобровільний характер переміщення; по-друге, факт того, що таке переміщення відбувається в межах державних кордонів [3]. Також у Керівних принципах зазначається, що переміщені особи мають право без будь-якої дискримінації користуватися тими ж самими правами і свободами відповідно до міжнародного і внутрішнього законодавства, що й інші громадяни у своїй країні. У Принципах зазначається, що внутрішньо переміщені особи не мають зазнавати дискримінації з причини їх переміщення, раси, статі, мови, релігії, етнічної чи соціальної приналежності або інших подібних факторів. 
Варто зазначити, що Принципи охоплюють увесь спектр питань, відповідно до яких може здійснюватися оцінка розвитку тієї чи іншої країни у покращенні становища ВПО у таких напрямах:

- запобігання переміщенню та мінімізація його негативних наслідків;

- підвищення обізнаності щодо проблеми в загальнонаціональних масштабах;

- збір даних щодо кількості та становища ВПО;

- організація навчання щодо прав ВПО;

- створення юридичних механізмів для захисту прав ВПО;

- розробка національної політики щодо внутрішньо переміщених осіб;

- створення інституцій, які б відповідали за вирішення проблем ВПО;

- заохочення національних правозахисних груп до залучення ВПО у їхню роботу;

- забезпечення участі ВПО у прийнятті рішень;

- підтримка системного вирішення проблем ВПО;

- залучення достатніх ресурсів для вирішення проблем;

- співпраця 3 міжнародними інституціями, якщо національних ресурсів не досить [3].

Принципи підтверджують той факт, що державні органи влади несуть основну відповідальність за забезпечення дотримання основних прав внутрішньо переміщених осіб на продукти харчування, житло, безпеку, честь і гідність паралельно з полегшенням їх доступу до інших прав. У разі неможливості надання допомоги і захисту внутрішньо переміщеним особам державні органи мають прийняти допомогу міжнародного співтовариства. Внутрішньо переміщені особи також мають право шукати притулку в іншій країні.

Одним із критично важливих показників національної відповідальності щодо реагування на внутрішнє переміщення є впровадження національної нормативно-правової бази, що визначає правовий статус ВПО. В українському законодавстві визначення внутрішньо переміщеної особи було сформульовано тільки після того, як настала криза внутрішнього переміщення. Анексія Криму у березні 2014 року та збройний конфлікт, що почався на Сході України в квітні 2014 року, призвели до масового переміщення цивільних осіб як усередині країни, так і за їі межі. Станом на 25 лютого 2019 року, за даними структурних підрозділів соціального захисту населення обласних та Київської міської державних адміністрацій, взято на облік 1364611 переселенців з тимчасово окупованих територій Донецької та Луганської областей та АР Крим.

У результаті переміщення внутрішньо переміщені особи в Україні зіштовхуються з ідентичними труднощами та проблемами, що і переміщені особи у всьому світі. Особливо гостро постають питання реєстрації як ВПО, відновлення втрачених документів, що посвідчують особу, свободи переміщення, доступу до житла, придатного для проживання, захисту прав власності, здобуття засобів до існування, реалізації виборчих прав, відшукання довготривалих рішень і доступу до інформації.

До стандартів відповідальності держави, включаючи основні заходи, під час використання яких можна ефективно досягти прийнятих на себе зобов'язань та забезпечити права ВПО, належать: попередження; залучення загальнонаціональної 
уваги до проблеми; збір персональних даних; навчання з питань прав ВПо; національне законодавство про захист прав ВПО; державна політика (план дій) щодо переміщення всередині країни; єдиний національний центр, який відає справами ВПО; роль національних інституцій з прав людини; участь ВПО в процесі вироблення рішень; довгострокові рішення; адекватні ресурси; співпраця з міжнародними і регіональними організаціями [7].

Перший досвід правового регулювання вимушеного внутрішнього переміщення в Україні було представлено Законом України «Про забезпечення прав і свобод внутрішньо переміщених осіб” від 20.10.2014 № 1706-VII. Прийняття національного закону про ВПО було схвалено багатьма національними та міжнародними інституціями. Водночас громадянське суспільство, депутати Верховної Ради та міжнародні організації привернули увагу до деяких недоліків у тексті Закону про ВПО, зокрема щодо визначення поняття ВПО. Це призвело до розробки законопроекту № 2166 «Про внесення змін до деяких законів України щодо посилення гарантії дотримання прав і свобод внутрішньо переміщених осіб». 3 листопада 2015 року Верховна Рада України підтримала законопроект № 2166. Однак 25 листопада 2015 року Президент України наклав вето на нього та повернув його для доопрацювання. Нарешті, 24 грудня 2015 року Парламент повторно проголосував за проект закону, а 6 січня 2016 року він був підписаний Президентом, у результаті чого було прийнято зміни до Закону про ВПО, зокрема до визначення поняття ВПО. Стаття 1 Закону України «Про забезпечення прав і свобод внутрішньо переміщених осіб» містить таке визначення ВПО: «Внутрішньо переміщеною особою є громадянин України, іноземець або особа без громадянства, яка перебуває на території України на законних підставах та має право на постійне проживання в Україні, яку змусили залишити або покинути своє місце проживання у результаті або з метою уникнення негативних наслідків збройного конфлікту, тимчасової окупації, повсюдних проявів насильства, порушень прав людини та надзвичайних ситуацій природного чи техногенного характеру» [2]. Враховуючи останні зміни № 2279-VIII від 08.02.2018, внесені до вказаного нормативно-правового акта, поняття ВПО, сформульоване в національному законодавстві, суперечить міжнародним стандартам у декількох аспектах. По-перше, воно звужує визначення, яке сформульовано в Керівних принципах з питання переміщення осіб усередині країни, тому що встановлює вимоги щодо громадянства та реєстрації місця проживання для ВПО. По-друге, щодо характеру переміщення визначення в національному законодавстві встановлює вичерпний перелік причин переміщення, а також не вказує на те, що внутрішнє переміщення має стосуватись вимушеного переміщення у межах міжнародно-визнаних національних кордонів. Крім того, визначення ВПО в національному законодавстві має третій недолік - воно встановлює особливий статус ВПО [5].

Важливим нормативним документом у національному законодавстві щодо правового регулювання внутрішнього переміщення $€$ Стратегія інтеграції внутрішньо переміщених осіб та впровадження довгострокових рішень щодо внутрішнього переміщення на період до 2020 року, схвалена розпорядженням Кабінету Міністрів України від 15 листопада 2017 р. № 909-р. Стратегія базується на таких принципах: 
- пріоритеті прав і свобод людини і громадянина загалом та внутрішньо переміщених осіб зокрема;

- верховенства права;

- відкритості і прозорості реалізації Стратегії з метою максимального залучення до її здійснення та моніторингу всіх заінтересованих сторін;

- політичної рівності;

- підтримки самоорганізації внутрішньо переміщених осіб;

- залучення внутрішньо переміщених осіб до діалогу щодо формування та реалізації державної, регіональної політики, вирішення питань місцевого значення, що стосуються їхніх прав та інтересів;

- залучення всіх інших заінтересованих сторін, включаючи центральні та місцеві органи виконавчої влади, органи місцевого самоврядування, громадські організації, а також міжнародних і національних гуманітарних партнерів та партнерів з розвитку, для співпраці з метою визначення правильних шляхів діяльності для виконання довгострокових рішень щодо внутрішнього переміщення та визначення критеріїв, що допоможуть визначити рівень виконання таких рішень [6].

Допоміжними документами у сфері правового регулювання вимушеного переміщення є такі нормативно-правові акти: Закон України «Про гуманітарну допомогу» від 22.10.1999 № 1192-XIV, Закон України «Про свободу пересування та вільний вибір місця проживання в Україні» від 11.12.2003 № 1382-IV, Закон України «Про забезпечення прав і свобод внутрішньо переміщених осіб» від 20.10.2014 № 1706-VII, Закон України «Про забезпечення прав і свобод громадян та правовий режим на тимчасово окупованій території України» від 15.04.2014 № 1207-VII, Закон України «Про створення вільної економічної зони «Крим» та про особливості здійснення економічної діяльності на тимчасово окупованій території України» від 12.08.2014 № 1636-VII, Закон України «Про тимчасові заходи на період проведення антитерористичної операції» від 02.09.2014 № 1669-VII, Постанова Кабінету Міністрів України «Про затвердження Порядку створення, ведення та доступу до відомостей Єдиної інформаційної бази даних про внутрішньо переміщених осіб» від 22.09.2016 № 646 та інші. Зазначимо, що, попри значну кількість нормативних документів у сфері регулювання вимушеного внутрішнього переміщення, є суттєві недоліки та прогалини у законодавчому забезпеченні вказаної сфери.

Висновки. Аналіз міжнародно-правового законодавства засвідчує, що процес примусового переміщення отримав своє правове закріплення з прийняттям Економічною та Соціальною Радою ООН Керівних принципів з питання переміщених осіб усередині країни (Guiding Principles on Internal Displacement, 1998). Визначення поняття «внутрішньо переміщена особа» встановлює конкретний перелік критеріїв, за наявності яких надається відповідний статус. У процесі дослідження встановлено, що національне законодавство містить певні недоліки у визначенні поняття «внутрішньо переміщена особа», що має негативний вплив на сферу захисту прав переміщених осіб, гарантій захисту та допомоги під час переміщення. Подальшу перспективу дослідження цієї теми становитиме більш детальний порівняльний аналіз міжнародної та національної нормативно-правової бази у сфері забезпечення конституційно-правового статусу переміщених осіб. 


\section{Jimepamypa}

1. Аналіз чинного законодавства України як основи для забезпечення прав внутрішньо переміщених осіб на здійснення підприємницької діяльності та інтеграції до соціально-економічного життя України. URL: http://www.ngoforum.org.ua/wp-content/uploads/2016/07/NGO_021_NEW_COLOR.pdf.

2. Вдосконалення національного законодавства України стосовно захисту прав людини внутрішньо переміщених осіб : Проект Ради Європи «Посилення захисту прав людини внутрішньо переміщених осіб в Україні». URL: http://www.ngoforum.org.ua/wp-content/uploads/2016/07/CoE-Report-onIDP UKR.pdf.

3. Керівні принципи ООН з питань внутрішнього переміщення (Guiding Principles on Internal Displacement). URL: https://www.ohchr.org/ Documents/Issues/IDPersons/GPUkrainian.pdf.

4. Права внутрішньо переміщених осіб: навчальний посібник / С.Б. Булеца, О.І. Котляр, Я.В. Лазур та ін.; за заг. ред.: д-ра юрид. наук, проф. О.Я. Рогача; д-ра юрид. наук, проф. М.В. Савчина. Ужгород : РІК-У, 2017. 436 с. ISBN 978-617-7404-69-8.

5. Права внутрішньо переміщених осіб: навчальний посібник / С.Б. Булеца, О.І. Котляр, Я.В. Лазур та ін.; за заг. ред.: д-ра юрид. наук, проф. О.Я. Рогача; д-ра юрид. наук, проф. М.В. Савчина. Ужгород : РІК-У, 2017. $436 \mathrm{c}$.

6. Про забезпечення прав і свобод внутрішньо переміщених осіб : Закон України від 20.10.2014 № 1706-VII. URL: https://zakon.rada.gov.ua/ laws/show/1706-18.

7. Про схвалення Стратегії інтеграції внутрішньо переміщених осіб та впровадження довгострокових рішень щодо внутрішнього переміщення на період до 2020 року : Розпорядження Кабінету Міністрів України від 15.11.2017 № 909-p. URL: https://zakon.rada.gov.ua/laws/show/909-2017-\% D1\% 80.

\section{Анотація}

Роговенко О. В. Аналіз міжнародних правових стандартів та національного законодавства у сфері забезпечення конституційного статусу переміщених осіб. - Стаття.

Здійснено аналіз міжнародної нормативно-правової бази, що регулює питання примусового переміщення. Досліджені особливості національного правового регулювання внутрішньо переміщених осіб порівняно з міжнародними стандартами. Встановлено, що сформульовані в національному законодавстві поняття певною мірою суперечать міжнародним стандартам, що ускладнює реалізацію прав внутрішньо переміщених осіб на практиці.

Ключові слова: примусове переміщення, внутрішньо переміщена особа (ВПО).

\section{Аннотация}

Роговенко О. В. Анализ международных правовых стандартов и национального законодательства в сфере обеспечения конституционного статуса перемещённых лиц. - Статья.

Осуществлен анализ международной нормативно-правовой базы, регулирующей вопросы принудительного перемещения. Исследованы особенности национального правового регулирования внутренне перемещённых лиц по сравнению с международными стандартами. Определено, что сформулированные в национальном законодательстве понятия в определённой степени противоречат международным стандартам, что затрудняет реализацию прав внутренне перемещённых лиц на практике.

Ключевые слова: принудительное перемещение, внутренне перемещённое лицо (ВПО).

\section{Summary}

Rohovenko $O . V$. Analysis of international legal standards and national legislation in the area of ensuring the constitutional status of displaced persons. - Article.

An analysis of the international legal framework governing the issue of forced displacement has been carried out. The peculiarities of the national legal regulation of internally displaced persons in comparison with international standards are investigated. It has been established that the concepts formulated in national legislation are to some extent contrary to international standards, which complicates the realization of the rights of internally displaced persons in practice.

Key words: forced displacement, internally displaced person (IDP). 